\title{
"Cieszę się z osiągnięć młodych ludzi” - z profesor dr hab. Hanną Tadeusiewicz rozmawia Marzena Przybysz
}

\author{
DOI: https://doi.org/10.18778/0860-7435.31.01
}

Marzena Przybysz: Pani Profesor, w 2020 r. przypadał Jubileusz 50-lecia obrony Pani doktoratu. Serdeczne gratulacje. $Z$ tej to okazji proszę pozwolić na przypomnienie wybranych dat i zdarzeń z Pani, jakże czynnego, życia zawodowego naukowego i dydaktycznego oraz aktywności społecznej.

Profesor dr hab. Hanna Tadeusiewicz: Działalność naukową i publikacyjna rozpoczęłam po studiach polonistycznych, pracując w Bibliotece Głównej Uniwersytetu Łódzkiego. Zajęłam się wówczas periodykami XIX w. Pogranicza literaturoznawstwa i czasopiśmiennictwa były tematem studiów opublikowanych w latach 1966-1976, m.in. w „Roczniku Historii Czasopiśmiennictwa Polskiego". Te prace jako pierwsze mojego autorstwa, sprawiły mi, na równi oczywiście z rozprawą doktorską z 1970 r., wielką radość.

MP: Proszę opowiedzieć o Pani Profesor początkach w zawodzie? W jakim stopniu praca w Bibliotece Głównej Uniwersytetu Lódzkiego ukształtowała Pani zainteresowania zawodowe?

HT: Pracę w Bibliotece UŁ, podjętą w 1965 r., zakończyłam w 1983 r. Zatrudniona zostałam w Oddziale Prac Naukowych. W 1978 r. objęłam funkcję jej kierownika. W ramach Oddziału pracowałam w redakcji przygotowywanego do druku Stownika pracownikón ksiażki polskiej, co dało mi wiedzę w zakresie biografistyki bibliologicznej i szerzej - nauki o książce. Ostatecznie (już po uzyskaniu stopnia doktora w 1970 r.), przystępując w 1972 r. do egzaminu państwowego na stanowisko bibliotekarza dyplomowanego, zadecydowałam 
o pozostaniu w zawodzie bibliotekarza. Tak więc praca w BUŁ ukształtowała mnie zawodowo i naukowo.

MP: W latach 1978-1982 pełniła Pani Profesor funkcję kierownika Oddziału Prac Naukowych przy pracach redakcyinych nad Słownikiem pracowników książki polskiej. W 1987 r. została Pani kierownikiem Katedry Bibliotekoznawstwa i Informacji Naukowej Uniwersytetu Lódzkiego. Od 1992 r. do struktury Katedry włączono Pracownię Słownika pracowników książi polskiej, którą Pani Profesor kierowała do 2010 r. Pod Pani redakcją zostały opracowane dwa suplementy Słownika, które ukazały się w 2000 r. i 2010 r. Prace były kontynuowane i po sześciu latach powstał kolejny - Suplement IV pod redakcja Magdaleny Rzadkowolskiej. Była Pani Profesor członkiem zespołu redakcyjnego. Suplementy zostały opublikowane przez Wydawnictwo Stowarzyszenia Bibliotekarzy Polskich w ramach Serii „Nauka-Dydaktyka-Praktyka”. Ta imponująca edycja wymagała wielu dociekliwych poszukiwań. Jak wspomina Pani prace nad Słownikiem? Które zagadnienia wymagały szczególnego wkładu w zebraniu materiału?

HT: Do redakcji Stownika pracowników ksiqżki polskiej trafiłam, muszę powiedzieć, przypadkowo. Szukając zatrudnienia po ukończeniu studiów zwróciłam się o pomoc do prof. Anieli Kowalskiej (promotor mojego magisterium). I to ona poleciła mnie Irenie Treichel do pracy w redakcji Stownika, funkcjonujacej w Oddziale Prac Naukowych, Organizacyjno-Naukowych i Dydaktycznych Biblioteki Uniwersytetu Łódzkiego. Zatrudniona w 1964 r. w trybie prac zleconych, od 1965 r. otrzymałam etat. I tak już, w zmieniającej się obsadzie personalnej, pozostałam w redakcji Stownika na długie lata. Z czasem objęłam funkcję redaktora naczelnego, realizując kolejne tomy suplementowe. Ostatni ukazał się pod redakcja Magdaleny Rzadkowolskiej w 2016 r. Ta blisko pólwieczna działalność dała mi dużo wiedzy, nauczyła skrupulatności, odpowiedzialności za słowo, dążenia do możliwie bezbłędnego opracowania autorskiego i redakcyjnego biogramów. Była to praca zespołowa, a ta wymaga umiejętności współpracy wszystkich członków zespołu. W opracowaniu materiałów biograficznych uczestniczyli bibliotekarze bibliotek publicznych, uczelnianych, naukowych z całej Polski. Ale do redakcji łódzkiej należało nadanie ostatecznego kształtu każdego życiorysu w kolejnym tomie Stownika. Było to trudne, ale niezmiernie kształcące i moge powiedzieć, że Stownik to wspólne działanie nie tylko bibliotekarzy, ale również księgarzy, wydawców, drukarzy, grafików książkowych, członków organizacji zawodowych, działaczy stowarzyszeń ludzi książki, pracowników nauki. I to był cel działalności nad kilkoma tomami Stownika. 
MP: W 2011 r. ukazał się Podręczny słownik bibliotekarza zawierający terminologię $z$ bibliotekarstwa, informacji naukowej i księgarstwa opracowany przez Grzegorza Czapnika i Zbigniewa Gruszkę przy współpracy Pani Profesor. Zapewne zaciekawi czytelników geneza tego przedsięwzięcia.

HT: Jak wiele wydawnictw zbiorowych, zwłaszcza tak obszernych, Podreczny stownik bibliotekarza ma długa historię i ciekawa genezę. Jego poprzednikiem jest Podreczny stownik bibliotekarza autorstwa Heleny Więckowskiej i Hanny Pliszczyńskiej opublikowany w 1955 r. Od tego czasu mijały lata, a nowego wydania tej publikacji nie było. Niezwykle przydatny słownik z 1955 r. powoli zdezaktualizował się. Konieczna więc była nowa, poszerzona jego edycja, która odpowiadałaby rozwojowi naszej dyscypliny naukowej i potrzebom odbiorców. Dopiero po 40 latach, w 1995 r. pracownicy Katedry Bibliotekoznawstwa i Informacji Naukowej podjęli się przygotowania nowej wersji słownika. Prof. Anna Sitarska, dr Józef Robowski i Jerzy Andrzejewski opracowali klasyfikacje rzeczowa haseł. Rozmaite wydarzenia wciąż hamowały prace redakcyjne. Po odejściu z Katedry Profesor Sitarskiej, kierował Pracownią dr Bogumił Karkowski, a po jego przedwczesnej śmierci (2004 r.) redakcję przejął dr Jerzy Andrzejewski. Nad słownikiem zawisło jakieś fatum. W 2008 r. zmarł J. Andrzejewski. Znów prace zostały przerwane, choć były już znacznie zaawansowane, przygotowany zostal obszerny materiał, szybko wprowadzono go do bazy. Kierując wówczas Katedra poprosiłam doktorów - Kolegów dr. Grzegorza Czapnika i dr. Zbigniewa Gruszkę o przejęcie i kontynuowanie prac. Moja niewielka rola w dalszych pracach sprowadzała się głównie do mobilizowania Panów Doktorów do szybkiej pracy i kontrolowania nieprzerwanego wysiłku. I tak dzięki wiedzy, ambicji i entuzjazmowi młodych ludzi z mojej Katedry wyszedł w $2011 \mathrm{r}$. od dawna oczekiwany Podreczny stownik bibliotekarza. Edycja ukazała się nakładem Stowarzyszenia Bibliotekarzy Polskich (w ramach serii „Nauka-Dydaktyka-Praktyka” oraz Uniwersytetu Lódzkiego). Wsparcia finansowego udzieliło Ministerstwo Nauki i Szkolnictwa Wyższego. Zakończenie dzieła i pozytywne o nim recenzje dały wszystkim współtwórcom (autorom, redaktorom, recenzentom) wiele satysfakcji.

MP: Przez wiele lat uczestniczyła Pani Profesor w pracach komitetu redakcyjnego serii wydawniczej „Nauka-Dydaktyka-Praktyka”. Jak kształtowała się tematyka tej serii?

HT: Seria wydawnicza „Nauka-Dydaktyka-Praktyka” realizowana jest od pó1 wieku przez Stowarzyszenie Bibliotekarzy Polskich. Cenią tę serię wysoko bibliotekarze, pracownicy nauki, studenci. Każdy tom serii opiniuje dwóch recenzentów - profesorów. Pracownicy nauki są członkami Komitetu Redakcyjnego, którzy m.in. decyduja o przyjęciu proponowanej książki do druku w ramach 
serii. Seria „Nauka-Dydaktyka-Praktyka” publikuje prace naukowe o tematyce historycznej i współczesnej, zagadnień dydaktyki, słowniki, monografie, np. czasopism, ludzie ksiażki itp.; profesjonalne wydawnictwo SBP gwarantuje wysoki poziom publikowanych dzieł zarówno merytoryczny jak i techniczny, a także graficzną urodę okładek.

MP: W latach 1984-2013 uczestniczyła Pani Profesor w pracach ministerialnej Komisji Egzaminacyjnej do przeprowadzania postępowania kwalifikacyjnego dla kandydatów na dyplomowanego bibliotekarza oraz dyplomowanego pracownika dokumentacji i informacji naukowej przy Ministrze Edukacji Narodowej (Nauki i Szkolnictwa Wyższego), pełniąc przez wiele lat funkcję zastępcy przewodniczącego tej Komisji oraz przewodniczącego.

Czy obecnie jest zapotrzebowanie na zawód bibliotekarza, czy wzrasta ranga tego zawodu i związany z nim prestiż i czy jest to zawód cieszący się zaufaniem społecznym?

HT: Przez 30 lat uczestniczyłam w pracach ministerialnej Komisji Egzaminacyjnej kwalifikującej pracowników bibliotek i instytutów dokumentacji i informacji naukowej na stanowisko pracowników dyplomowanych w tych instytucjach. Byli oni po złożeniu egzaminu przeznaczani na stanowiska kierownicze i dyrektorskie, stanowili niejako elitę w zawodzie, mieli bowiem dorobek publikacyjny, osiagnięcia naukowe, dydaktyczne i organizacyjne, a także udokumentowaną znajomość języka obcego. Uzyskanie takiego stanowiska świadczyło o przygotowaniu w stopniu wyższym do zawodu, podnosiło jego prestiż. Było to egzamin trudny (sama go zdawałam), ale otwierał drogę do awansu. Likwidacja Komisji i stanowiska pracowników dyplomowanych obniża, moim zdaniem, rangę zawodu i społeczne zaufanie do pracujących w nim osób.

MP: Kontynuując rozważania nad rolą naszego zawodu, czy uważa Pani Profesor, że bibliotekarz powinien mieć powołanie?

HT: „Powołanie” w stosunku do bibliotekarzy jest określeniem nieco na wyrost. Może wystarczałoby, gdyby do zawodu trafiali ludzie zainteresowani pracą z czytelnikiem starszym i młodszym, z książką tradycyjną i elektroniczną, żeby iść $z$ duchem czasu.

MP: Jest Pani Profesor członkiem wielu stowarzyszeń i towarzystw. Do Stowarzyszenia Bibliotekarzy Polskich wstąpiła Pani Profesor w 1969 r. Już wówczas była to liczna organizacja. Czy pamięta Pani moment przystąpienia? Co Panią Profesor do niej przyciągnęło?

HT: Pracując od kilku lat w Bibliotece Uniwersyteckiej w Łodzi miałam kontakt z koleżankami i kolegami, którzy byli członkami Stowarzyszenia Bibliotekarzy Polskich, pełniąc często różne funkcje w Okręgu Lódzkim i Zarządzie 
Głównym Stowarzyszenia. Kończąc rozprawę doktorską, miałam już więcej czasu, zainteresowałam się działalnościa tej organizacji. Słyszałam, że jest to stowarzyszenie o charakterze zawodowym i dobrze byłoby do niego należeć, do czego zachęcił mnie starszy kolega Janusz Dunin. I tak w 1969 r. zostałam członkiem SBP.

MP: Jaką główną działalnością charakteryzowało się ówczesne Stowarzyszenie Bibliotekarzy Polskich? Jakie cenne inicjatywy podejmowało?

HT: Działalność Stowarzyszenia w latach, gdy do niego wstapiłam, była bardzo wszechstronna. Obejmowała dokształcenia bibliotekarzy, zwłaszcza najmłodszych, organizowanie konferencji naukowych i popularnonaukowych, jubileuszy własnej działalności i zasłużonych członków w strukturach lokalnych i ogólnopolskich. Ważne było z pewnością uczestniczenie członków Zarządu w wydarzeniach kulturalnych w Okręgach i w całym kraju, a także dbanie o stan finansowy bibliotekarzy. Bardzo cenną inicjatywą było podejmowanie prac wydawniczych, publikacji czasopism o różnym profilu wychodzących wiele lat oraz licznych książek wydawanych w kilku seriach adresowanych do różnych odbiorców. Zarówno czasopisma jak i książki wydawane przez SBP cieszą się do dziś popularnością i uznaniem licznych czytelników.

MP: Pani Profesor zasiadała w licznych radach i komisjach bibliotek, konkursów, redakcji Komisji Nagród Stowarzyszenia Bibliotekarzy Polskich, od 2004 r. brała udział w pracach Zespołu do spraw opracowania kodeksu etyki bibliotekarza i pracownika informacji Stowarzyszenia Bibliotekarzy Polskich. Była to niezwykle ważna inicjatywa.

HT: Istotnie uczestniczyłam od $2004 \mathrm{r}$. w pracach powołanego Zespołu do spraw przygotowania do druku Kodeksu etyki bibliotekarza i pracownika informacji nankowej. Kodeks taki ukazał się w wydawnictwie Stowarzyszenia Bibliotekarzy Polskich. Była to niewątpliwie cenna inicjatywa, ale (o ile pamiętam) kodeks większego odzewu nie znalazł.

MP: Jest Pani Profesor promotorem ponad 200 licencjatów i magistrów oraz 13 doktorów w zakresie bibliologii. Była Pani Profesor również w Jury konkursu Nagrody Młodych SBP im. Prof. Marii Dembowskiej dla absolwentów bibliotekoznawstwa i informacji naukowej na najlepsze prace magisterskie. Pani dorobek naukowy obejmuje setki publikacji. Jest Pani Profesor recenzentem rozpraw doktorskich, habilitacyjnych, dorobku naukowego do wniosków o tytuły profesorskie, wniosków o dotacje oraz opinii dla wydawnictw. Została Pani także członkiem Komisji Nagrody Naukowej Stowarzyszenia Bibliotekarzy Polskich im. Adama Łysakowskiego. Czy któraś z ocenianych przez Panią Profesor prac zapadła na trwałe w pamięci? 
HT: W latach 2000-2013 wchodziłam w skład Komisji Nagrody Stowarzyszenia Bibliotekarzy Polskich im. profesor Marii Dembowskiej. Tę nagrodę otrzymywali w wyniku konkursu młodzi absolwenci studiów za najlepszą pracę magisterską z zakresu bibliotekoznawstwa i informacji naukowej. Celem tego konkursu było promowanie młodych adeptów nauki, motywowanie ich do dalszej pracy. W 2002 r. zostałam powołana na członka Komisji Nagrody Naukowej SBP im. Adama Łysakowskiego. Ta nagroda promowała w środowisku bibliotekarskim autorów, których dzieła maja istotne znaczenie dla rozwoju naszej dyscypliny. W wymienionych Komisjach pracowałam od 2002 r. i trudno mi po blisko 20 latach wskazać autorów i tytuły nagrodzonych książek i prac magisterskich.

MP: Brała Pani Profesor udział w radach naukowych i programowych wielu ogólnopolskich konferencji bibliotekarskich, między innymi, pamiętam, w Radzie Programowej Sesji Jubileuszowej w 100 rocznicę śmierci Karola Estreichera w 2008 r. Jak wspomina Pani Profesor ten czas aktywności naukowej?

HT: Z pewnością był to czas intensywnej pracy naukowej i organizacyjnej. Trzeba było należycie uczcić wybitnego Polaka i uczonego Karola Estreichera, godnie przyjać znakomitych gości z kraju i zagranicy. Zaangażowanie i wspólna praca m.in. Rady Programowej Sesji Jubileuszowej w 100 rocznicę śmierci Karola Estreichera w 2008 r. dały bardzo dobry wynik, pisano i mówiono o tej sesji jeszcze długo po jej zakończeniu.

MP: Proszę opowiedzieć, w jaki sposób oprócz konferencji, środowisko bibliotekarskie nawiązywano kontakty, jaka była rola krajowych ośrodków bibliotekarskich?

HT: Konferencje, sympozja, zjazdy ogólnopolskie, regionalne i lokalne organizowane przez SBP były miejscem spotkań bibliotekarzy z różnych bibliotek. Miały one charakter kształcący i integracyjny zarazem. Pozwalały poznać kolegów zatrudnionych w bibliotekach funkcjonujących na terenie całej Polski, nawiązać znajomości, kontakty zawodowe i naukowe, także przyjaźnie, ułatwiały współpracę bibliotek i bibliotekarzy, osób działających w instytucjach oświaty i kultury, pracowników ośrodków kształcenia bibliotekarzy na poziomie średnim, również Instytutów i Katedr polskich uczelni wyższych. Przewodniczący zarządów Okręgów zapraszali na spotkania z referentami pisarzy, poetów, uczonych, artystów - ludzi znanych i mniej znanych, ale wartych poznania. Interesowały takie spotkania lokalną społeczność.

MP: Za działalność naukową i dydaktyczną została Pani Profesor uhonorowana wieloma odznaczeniami i nagrodami. Za wybitną i szczególną działalność na rzecz upowszechniania bibliotekarstwa otrzymała Pani w 1999 r. 
Honorową Odznakę Stowarzyszenia Bibliotekarzy Polskich. Czym dla Pani jest członkostwo w tej organizacji?

HT: Otrzymana odznaka i nagrody za działalność na rzecz SBP sa dla mnie ważne i satysfakcjonujące. Pracując w Stowarzyszeniu znacznie poszerzyłam swą wiedzę w zakresie bibliotekarstwa i bibliotekoznawstwa, poznałam wielu ludzi wybitnych, uczonych, społeczników, autorów artykułów i książek, których lektura wiele mnie nauczyła - zwłaszcza, że kończyłam studia polonistyczne, a nie bibliotekarskie, co mi nie przeszkodziło w zdobyciu stanowiska bibliotekarza dyplomowanego.

MP: Pani Profesor działając na wielu płaszczyznach łączyła pracę naukowa dydaktyczną, redaktorską $z$ działalnością społeczną. $W$ jaki sposób udawało się to powiązać, czy wymagało weryfikacji planów?

HT: Ta wielostronna działalność prowadzona przeze mnie przez pół wieku, zaangażowanie na polu nauki i dydaktyki, także w działalności społecznej wymagała oczywiście czasu i pracy. Jeśli jednak lubi się jakąś pracę i ma się przekonanie, że jest potrzebna i komuś służy, że lubi się relacje - dobre oczywiście - z ludźmi starszymi i młodszymi - to jest możliwe połączenie różnorodnej działalności i takie jej zorganizowanie, żeby jeszcze zostało nieco czasu na życie osobiste.

MP: Czy możemy porozmawiać o zdarzeniach oraz osobach, które w Pani Profesor życiu odegrały istotną rolę?

HT: Na mojej drodze spotkałam osoby bardzo mi życzliwe, które pomogły mi w pracy zawodowej i naukowej, w osiaganiu kolejnych szczebli w karierze uniwersyteckiej (w Bibliotece i Katedrze UZ). Wspominam z wdzięcznością prof. Anielę Kowalską - promotora mojej pracy magisterskiej i rozprawy doktorskiej, która motywowała mnie do szybkiego zakończenia książki habilitacyjnej, umożliwiła referowanie wyników podjętych studiów w Komisji Historii Literatury Lódzkiego Towarzystwa Naukowego. Również znaczący wpływ na moją drogę naukową wywarła dr Irena Treichel, która wprowadziła mnie do zespołu redakcyjnego Stownika pracowników ksiażki polskiej, nauczyła pracy biograficznej, inspirowała do badań bibliologicznych i czasopiśmienniczych. Obie Panie otaczały mnie opieka, oceniały przeznaczone do druku artykuły. Z czasem zyskałam ich sympatię i przyjaźn, co bardzo sobie ceniłam. Przez wiele lat współpracowałam z prof. Jerzym Starnawskim, który wprowadził mnie do Lódzkiego Towarzystwa Naukowego, którego członkiem jestem do dziś. Pan profesor ofiarował mi swoje publikowane prace naukowe, często z serdecznymi dedykacjami. Życzliwym recenzentem mojej rozprawy doktorskiej była prof. Helena Więckowska. Ona też rekomendowała moje prace do 
druku na łamach „Roczników Bibliotecznych”. Wszyscy wymienieni uczeni już nie żyją, pożegnałam ich wspomnieniami pośmiertnymi, biogramami w Słowniku, zestawiłam Ich naukowy dorobek w bibliograficznych spisach.

MP: Jest Pani Profesor osobą otwartą na ludzi młodych. Co chciałaby Pani przekazać będącym na początku drogi w zawodzie bibliotekarskim?

HT: Od początku pracy w Uniwersytecie Lódzkim (jako doktor, doktor habilitowany i profesor) prowadziłam pracę dydaktyczną. Lubiłam bardzo kontakty z młodzieżą, od której też się wiele nauczyłam, obserwując (na wykładach, proseminariach i seminariach) studentów, nawiązując z nimi przyjazne i przyjacielskie stosunki, wprowadzając młodych ludzi w świat nauki i zawodu bibliotekarza.

MP: Proszę opowiedzieć o Pani Profesor aktualnych fascynacjach.

HT: Po blisko 60-ciu latach pracy organizacyjnej, badawczej i dydaktycznej dziś cieszę się z osiagnięć młodych ludzi w zakresie informatologii i bibliologii, szczególnie z wyników badań nad historią książki i bibliotek, czasopism i biografistyki. Moje fascynacje odnoszą się obecnie do przeszłości, do prawdziwej radości z sukcesów moich wychowanków, których magisteria i doktoraty prowadziłam, książki habilitacyjne i dorobek profesorski Kolegów recenzowałam chyba ze wszystkich ośrodków uniwersyteckich w Polsce, także pracowników bibliotek naukowych, głównie z Lodzi.

MP: Dziękuję serdecznie za rozmowę. Życzę zdrowia i realizacji planów.

HT: Dziękuję.

Rozmawiała: Marzena Przybysz

Stowarzyszenie Bibliotekarzy Polskich 